\title{
Green energy in municipal planning documents
}

\author{
Anna Bazan-Krzywoszańska ${ }^{1,{ }^{*}}$, Marta Skiba ${ }^{1}$, Maria Mrówczyńska ${ }^{1}$, Matgorzata \\ Sztubecka ${ }^{2}$, Dorota Bazuń $^{3}$, Mariusz Kwiatkowski ${ }^{3}$ \\ ${ }^{1}$ University of Zielona Góra, Faculty of Civil Engineering, Architecture and Environmental \\ Engineering, 1 prof. Z. Szafrana St., 65-516 Zielona Góra, Poland \\ ${ }^{2}$ University of Science and Technology, Faculty of Civil and Environmental Engineering and \\ Architecture, 7 prof. S. Kaliskiego St., 85-796 Bydgoszcz, Poland \\ ${ }^{3}$ University of Zielona Góra, Faculty of Education, Psychology and Sociology, 69 Wojska Polskiego \\ St., 65-762 Zielona Góra, Poland
}

\begin{abstract}
Urbanization causes many changes to the land management system. It is estimated that cities are responsible for $75 \%$ of the total energy consumption, and in 2045 they will be inhabited by about $70 \%$ of the world's population. These are the reasons why they should be reflected upon with regard to the problem of environmental protection, and further by means of energy production from renewable energy sources, an efficient public transport system, or securing green areas in a city space. In protecting the natural environment, urban development policy should, according to the guidelines of the European Union, be adapted to the requirements for the reduction of the need for heat, electricity and gaseous fuels. The EU directives indicate the need to increase the share of renewable energy in final consumption (in the first stage, up to $15 \%$ ) and to reduce $\mathrm{CO} 2$ emissions by $20 \%$. The aim of the article is an attempt to determine how to implement green energy into cities through planning documents. Material for analysis was obtained from standardized interviews carried out with the inhabitants of Zielona Góra and the documents which are the base to the implementation of the Urban Energy Audit (EAM). Policy concerning the introduction of green energy to cities should primarily be determining tasks to carry out at a national (centralized) and local (decentralized) level. Tools to implement this vision at a local level shall be, inter alia, municipal planning documents.
\end{abstract}

\section{Introduction}

The need to adjust the urban development policy to the requirements of the European Union in terms of reducing greenhouse gas emissions is a challenge for Poland. It requires comprehensive actions that will lead to a reduction in the operational demand for heat, electricity and gaseous fuels. The consequence of adopting such policy is also an attempt to take actions which lead to the use of renewable energy sources, so-called green energy in urban areas. There is one aspect of renewable energy development at a local and regional level. The adoption of such policy is associated with the implementation of its findings into

\footnotetext{
* Corresponding author : A.Bazan@aiu.uz.zgora.pl
} 
documents shaping a policy of urban development, including planning documents, that is a municipal study of the conditions and directions of the spatial planning and local zoning plans.

The Strategy of Development of Renewable Energy [1], Polish Energy Policy up to 2030 [2], the Program for the Power Sector [3], the Act - Energy Law [4], the Act on biocomponents and biofuels [5], the Act on Energy Efficiency [6], or the Act on Renewable Energy Sources [7], as the documents implemented at the national level, indicate the overall strategy. Independent public opinion surveys carried out among local authorities in 2013 have shown that nearly $69 \%$ see the chance to develop Renewable Energy Sources in Poland. $61 \%$ of the respondents find these activities an investment in the future; and nearly half of them sees these investments as the for additional profits for the local budget. A threat to municipalities from green electricity is predicted by nearly $7 \%$ of the respondents [Kras, 2018]. Carrying out tasks related to Renewable Energy Sources is the duty of the ministries responsible for the environment (promotion, climate change, nature 2000, hydropower, geothermal energy, forest biomass), the economy (energy efficiency, Renewable Energy Sources in power sector and heating, biofuels), agriculture (production of biomass and fuel biocomponents), construction (thermal renovation, passive architecture) and maritime affairs (wind farms at sea). The institutions providing investment aid in terms of RES investment include institutions of the State and commercial banks $[2,9,10]$.

The policy associated with the introduction of green energy to cities should be based on the following principles: energy planning must be coordinated with the overall planning for the city's development, the energy system should promote local renewable energy by applying appropriate systems and technologies, including the promotion of the local energy industry. It should also be ensured that all types of specialized planning can exist optionally $[11,12]$. A city, because of the concentration of the population will play an important role in the development of green energy, also in terms of improving the vision of energy planning concerning the economy and efficiency in all sectors of the energy industry. Taking this into account, it must be assumed that there is a need to specify the tasks needed to be carried out at the national (centralized) and local (decentralized) level in terms of the implementation of the European Union's vision regarding the use of green-renewable energy [13]. Such an approach to the problem requires a strategic planning system.

\subsection{Zielona Góra}

The study presented in this paper has been done for the city of Zielona Góra, located in the western part of Poland. Data which characterize the condition of construction in Zielona Góra reflect the average condition of construction throughout Poland. These data include: the size of the average usable floor area of an apartment, which is $61.5 \mathrm{~m}^{2}$ in Zielona Góra (average in Poland $62.5 \mathrm{~m}^{2}$ ), the size of the average usable area per person, that is $24.6 \mathrm{~m}^{2}$ (average in Poland $24 \mathrm{~m}^{2}$ ), constantly increasing the number of both residential buildings and apartments, a steady increase in the size of the usable area of apartments and a steady increase in the quality and standard of residences.

In Zielona Góra, as in most Polish cities, the structure of the buildings is varied. Dense frontage development using traditional technology occurs in the old town, where carbon heating equipment is still in use. These are often residential and commercial-residential buildings. There are also single-family and multi-family buildings from the 1950s -1970 s in the city centre, with gas as the major source of heat energy. Because of the technology implemented and the quality of the used materials, they are very energy-intensive buildings, often not thermally insulated. Users of these buildings often choose the most inexpensive energy carriers, which are still solid fuels. The old town and the city centre are surrounded 
by a ring of housing estates with residential multi-family buildings constructed at various periods from the $1950 \mathrm{~s}$ to the present. The estates are characterized by traditional or industrialized technology of the development implementation. Detached, semi-detached and terraced houses built in traditional technology, are mainly located in the suburbs $[14,15]$.

\section{Strategic documents}

The directives of the European Union concerning the increase in the share of renewable, green energy in the final consumption of the community countries, have been implemented into the strategic documents of all the member states. Fig. 1 presents the system of implementation of energy policy and RES in Poland. The level of transposition of EU directives into the national legislative system does not have a reference in documents shaping the policy of development of the region or municipality.

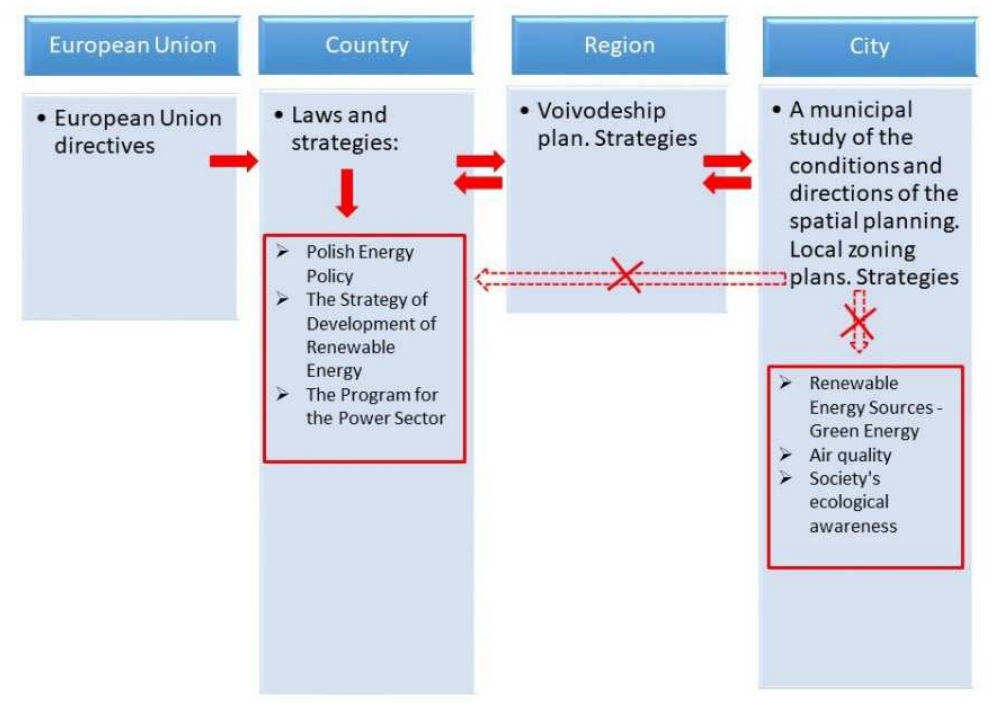

Fig. 1. Strategy documents shaping energy policy.

As a result, in documents shaping the policy of development at the local level there are no arrangements for green energy, findings in terms of activities having an impact on air quality. Apart from that, the environmental awareness of the residents does not give opportunities for dialogue, and thus does not allow the possibility of introducing a system based on social participation in local action for the system.

\section{Methodology}

\subsection{Area of study}

The area of research focused on the urban areas of Zielona Góra, designated on the basis of its distinctive residential buildings. The city was divided into 52 districts, differentiated in terms of the buildings' functions, construction technologies, construction date and technical condition. The data from the research carried out in 2011 for the Energy Urban Audit for Zielona Góra [16-18] have been assumed in the created model. The study focused on the city of Zielona Góra, in its 2015 administrative borders. 


\subsection{Surveys Reasearch}

In July, 2016 pilot surveys were conducted. The study focused on the willingness of Zielona Góra residents to pay greater attention to the environment and to reduce energy consumption, which is associated with temporary inconveniences during modernization works and long-term expenses, that shall increase the rent so as to cover the costs of investment. The research sample was not representative of the entire population. The respondents were chosen intentionally. Their households were located in the zones highlighted within the framework of the Urban Energy Audit [14]. 53 standardized interviews were carried out. To gain more cross-cutting results, data from nationwide, representative results were also used [16-18]. The data were developed with the use of artificial neural networks, therefore the approximation of acceptance for increased charges for electricity from RES by the inhabitants was possible at any point in the research area. Notes and digressions of respondents concerning the matter of the questionnaire were also recorded.

The questionnaire included questions about:

a) occupied property (type and age of the building, kind of rights to the property, area and number of people living in it, thermal insulation in the building, the window for thermal insulation, kind of heating);

b) assessment of the importance of the issues relating to environmental pollution, readiness to bear the increased cost in case of using energy from RES;

c) willingness for changes and investments in order to increase energy and heat savings;

d) assesment of the financial situation made by the respondents themselves.

An important element of the research was the residents' willingness to change. Table 1 lists the activities concerning the use of green energy that the inhabitants of Zielona Gora were asked about, and their potential willingness to participate in them and incur financial expenses.

Table 1. Possible actions within the modernization of buildings with the use of green energy.

Remediation actions with the use of renewable energy sources, heat pumps, and combined heat and power
Installation of a mechanical exhaust system with a heat recovery-recuperator individual/collective).

Installation of a mechanical exhaust system (installments, grilles, ventilators).

Installation of hygroregulated ventilators. Implementation of a solar energy system (solar panels, fittings).

Implementation of a photovoltaic system (photovoltaic panels, fittings).

Greywater recovery system implementation (tanks, fittings, installation of the toilet). Installation of LED lighting in the corridors, stairwells and in front of the entrance.

Replacement of passenger lifts with energysaving ones.

Replacement of a central heating and domestic hot water boiler with a biomass boiler.

Use of heat pumps.

Use of a combined heat and power system.

Survey results indicated that the modernization of existing buildings and building new ones in accordance with energy efficient technologies requires appropriate funding. In 
general statements, the inhabitants of Zielona Góra, find caring for the environment an important (or fairly important) problem, however, they are less likely to incur any costs resulting from the use of RES energy, or modernization of the buildings they live in. During the pilot study, it became apparent that the question of a willingness to "implement a wind power plant system (windmills, fittings)" was unfounded, due to the fact that it simply could not be implemented in urban areas.

\section{Discussion}

The literature shows no examples of research, estimation and prediction-modeling, including projects at the level of planning documents for the introduction of a power management system, in particular, green energy, for urban areas and cities of Eastern Europe,. A number of works is based on a studies of particular buildings (especially residential ones) but these are not analyses on a city scale. A shortage of such research may be the result of negligence in documentation (no digital maps, datasets, systems of monitoring spatial change in the city scale). These types of problems also occurred in Zielona Góra. The prepared Town Energy Audit for Zielona Góra [14] was the first document of its kind, though not implemented (mainly due to the economic and political effects).

Current models of forecasting energy demand can be compared to the economic model, which takes into account the size of the GDP (gross domestic product), the population and the size of the industry, the cost of environmental protection as well as the perspective outlined by a social engineering analysis [19- 20-23]. Long-term trends in electricity demand in the country, which are the basis for shaping the local energy policy, are predicted. At the same time, at the local level the volume of demand for energy, depending on how to provide power to the building, heating and cooling equipment is forecasted, having regard to factors such as climate, the technical condition of a building and its physical properties and the standard associated with appliances it is fitted with. To estimate the demand for media, energy suppliers increasingly build forecasting models using, e.g. artificial neural networks. It is rare, however, to use a simulation of energy use that supports the optimization of management of cities.

The traditional model of an energy system, based on fossil fuels, was built on the following principles:

-centralized production of electricity and heat and transport management,

- limited central planning and energy policy,

-restrictions in the supply of fuels,

- limitations on the number of energy producers, passive consumers,

- growing demand for energy, targeted production.

This system is reflected in municipal planning documents, which completely ignore the aspect of energy or economic efficiency as part of the planned new investment areas.

Target model of thinking about urban development, needs to take into account the systems with the following features:

-consumption of fossil fuels is minimal or nil, also when it comes to transport,

-a variety of interrelated production technologies and producers is allowed

-assumption of full integration in the production of energy, heat and transport systems service,

-consumers and producers of energy and heat react to fluctuations in production and demand in real time,

-demand for energy is related to a continuous improvement in energy efficiency, also with the use of RES. The consequences of such a policy should be attributed to the 
various initiatives of the legislator (centralized), as well as local governments (decentralized) $[13,24]$. They treat planning documents, including studies on the conditions and directions of spatial planning and local zoning plans, as policy tools indicating directions of development. They are also tools that, properly constructed, allow monitoring and balancing changes taking place in the area at a certain time. Knowledge acquired in this way is completely unused in the current system of urban space management.

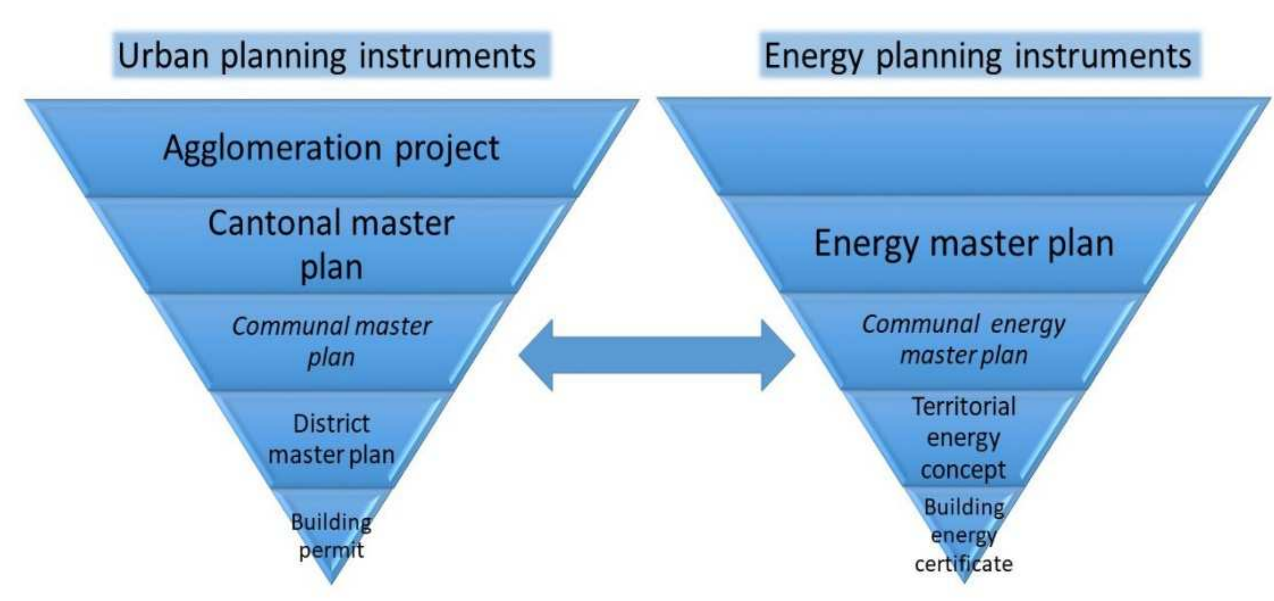

Fig. 2. Urban and energy planning instruments [based on Cajot et al, 2017].

The case study of Geneva presenting such a way of thinking about city planning is possible and brings real economic effects (Fig. 2). It also shows how serious the restructuring of an attitude towards planning and its administrative management within the created structure is necessary to get satisfactory results. Changing the scale of analysis from a building level to a city district level, while taking into account energy neighborhood and energy efficiency, and the residents being generally aware of the costs and benefits of such action, results in solutions based on a deliberate compromise. However, the local specifics of the place will always be a dominant factor in the final decision that planners make to determine profits and losses for specific variants of solutions [25].

\section{Conclusion}

Appropriate planning for urban development, within planning documents, using opportunities to plan renewable- green energy, makes the reasonable management of energy feasible. It is also possible to improve energy efficiency and optimize power management within the city. This type of approach to green energy gives the opportunity for urban development with respect for natural resources.

Another aspect that requires immediate action is the need to change the awareness of the inhabitants. Every fourth respondent to the questionnaires were apathetic about how their way of life impacted the environment. So it is important, on the one hand, to raise residents' awareness of needs and challenges related to the protection of the environment (which they are a part of), yet on the other hand, to indicate the positive consequences of investments in RES and green energy, which will bring real savings in the future. The best argument in 
this case may be preparing a cost estimate and showing what benefits it can bring to the household budget. Education in terms of consumer habits, to show what actions will bring real savings at a household level is also important.

\section{References}

1. The Strategy of Development of Renewable Energy. (2011) www.nape.pl/upload/file/akty-prawne/strategie-rozwoju/strategia_rozwoju_ enodnawialnej.pdf (Accessed date: 2018.04.25)

2. Polish energy policy up to 2030. www.pigeor.pl (Accessed date: 2018.04.25)

3. Program for the Power Sector. (2016) www.msp.gov.pl/pl/przeksztalcenia/dokumentystrategiczne/programy-i-strategie/30081,Program-dla-elektroenergetyki.html (Accessed date: 2018.04 .25 )

4. The Act of 10 April 1997. Energy Law (Off. J. of 2018, item. 755, 650, 685 and 771)

5. The Act of 25 August 2006 on biocomponents and liquid biofuels (Off. J. of 2015 item 775)

6. The Act of 20 May 2016 - Energy Efficiency Law (Off. J. of 2016 item 831)

7. The Act of 20 February 2015. Renewable Energy Sources (Off. J. of 2017 item 1148)

8. M. Kras, Aspekty planistyczne i środowiskowe dotyczące Odnawialnych Źródeł Energii. $\quad$ http://www.demokracjaenergetyczna.pl/uploads/images/pdf/Prezentacja Marek_Kras_Gliwice.pdf (Accessed date: 2018.04.25)

9. Evaluation of the implementation of energy policy since 200. www.polishwindenergy.com (Accessed date: 2018.04.25)

10. Demand for fuel and energy to 2030 forecast. www.me.gov.pl/Energetyka/Polityka+energetyczna (Accessed date: 2018.04.25)

11. J. ChunXia, L. Zhong, Z. Hao, G. JiMeng, Energ Procedia 143, 891-895 (2017)

12. Sz. Szewrański, J. Chruściński, J. Kazak, Water 10, 386 (2018)

13. K. Sperling, F. Hvelplund, B. Vad Mathiesen, Energ Policy 39, 1338-1351 (2011)

14. Energetyczny Audyt Miejski dla miasta Zielona Góra (Urban Energy Audit), Research task 1: Analysis of the possibilities and socio-economic impact of raise in energy efficiency in the construction industry. Contract No SP/B/1/91454/10, NCBiR 2010, Zielona Góra 2011

15. A. Bazan-Krzywoszańska, M. Mrówczyńska, M. Skiba, A. Łączak, Energ Buildings 118, 170-180 (2016)

16. CBOS Report no 28/2016. The Future of Poland's Energy Supply, Warszawa. https://www.cbos.pl (Accessed date: 2018.04.25)

17. CBOS Report no 32/2016. Energetics and Ecology - Declarations and Attitudes, Warszawa. https://www.cbos.pl (Accessed date: 2018.04.25)

18. CBOS Report no 36/2016. Energy Conservation and Prosumer Energetics, Warszawa. https://www.cbos.pl. (Accessed date: 2018.04.25)

19. E. Asadi, M. Silva, C. Antunes, L. Dias, Build Environ 56, 370-378 (2012)

20. D. Fouquet, Th. Johansson, Energ Policy 36, 4079-4092 (2018)

21. W. Labiosa, W. Forney, A. Esnard, D. Mitsova-Boneva, R. Bernknopf, P. Hearn, D. Hogan, L. Pearlstine, D. Strong, H. Gladwin, E. Swain, Environ Modell Softw 41, 210 $222(2013)$

22. J. Webb, D. Hawkey, M. Tingey, Cities 54, 28-35 (2016) 
23. C. Topi , E. Esposto, V.M. Govigli, Environ Sci Policy 58, 74-82 (2016)

24. M. Mrówczyńska, A Alsabry., M. Skiba, A. Bazan-Krzywoszańska, Int J Eng Sci and Innov Tech (IJESIT) 3 (5), 373-384 (2014)

25. S. Cajot, M. Peter, J.M. Bahu, F. Guignet, A. Koch, F. Maréchal, Sustain Cities Soc 30, 223-236 (2017) 